\title{
Rubber (Hevea brasiliensis) seed oil toxicity effect and Linamarin compound analysis
}

\author{
Jumat Salimon*, Bashar Mudhaffar Abdullah and Nadia Salih
}

\begin{abstract}
Background: The lipid fraction of rubber (Hevea brasiliensis (kunth. Muell)) seed was extracted and analyzed for toxicological effect. The toxicological compound such as linamarin in rubber seed oil (RSO) extracted using different solvents, such as hexane $\left(\mathrm{RSO}_{h}\right)$, mixture of chloroform + methanol $\left(\mathrm{RSO}_{\mathrm{chl}+\mathrm{mth}}\right)$ and ethanol $\left(\mathrm{RSO}_{\text {eth }}\right)$ were also studied. Various methods analysis such as Fourier transforms infrared spectroscopy (FTIR) and colorimetric methods were carried out to determine the present of such compounds.

Results: FTIR spectrum of RSO did not show any presence of cyanide peak. The determination of cyanide by using colorimetric method was demonstrated no response of the cyanide in RSO and didn't show any colored comparing with commercial cyanide which observed blue color. The results showed that no functional groups such as cyanide $(C \equiv N)$ associated with linamarin were observed. Toxicological test using rats was also conducted to further confirm the absence of such compounds. RSO did not show any toxic potential to the rats. Bioassay experiments using shrimps had been used as test organisms to evaluate the toxicity of linamarin extract from $\mathrm{RSO}_{h}, \mathrm{RSO}_{\text {chl+mth }}$ and $\mathrm{RSO}_{\text {eth }}$ and LC50 were found to be $(211.70 \%, 139.40 \%$, and $117.41 \%$, respectively).
\end{abstract}

Conclusions: This can be attributed no hazardous linamarin were found in RSO.

Keywords: Rubber seed oil, Linamarin, Toxicity, Colorimetric method, Rats, Shrimps

\section{Background}

Recently, production of rubber seed oil (RSO) shows a huge increase in both quantity and quality in Asia. This is because of its important role in different industrial processes. RSO is yellow in color with a semi-drying oil characteristic [1]. The oil does not contain any unusual fatty acids, and its rich source of essential fatty acids (C18:2 and C18:3) make up $52 \%$ of its total fatty acids composition $[2,3]$.

There is a compelling reason to explore the further commercial and pharmacological benefits of low priced and unconventional sources of RSO, such as Exploration of inexpensive sources of vegetable oils has become imperative in countries like South East Asia [4]. Chemically RSO is composed of TAG of saturated and unsaturated fatty acids. The unsaturated fatty acids are monounsaturated (oleic 18:1) and polyunsaturated such as (linoleic 18:2), or (linolenic 18:3) carboxylic acids [1].

\footnotetext{
* Correspondence: jumat@ukm.my

School of Chemical Sciences and Food Technology Faculty of Science and Technology, Universiti Kebangsaan Malaysia, 43600, Bangi, Selangor, Malaysia
}

However many studies that have been carried out in the rubber seed (RS) field indicated that the production of the RSO is facing various vital challenges and one of which is the toxin, which can lead to health problems. It is well-known that concentration of poisons may always be found in the seeds of all types of plants. One of these plants that contain toxin elements is the seeds of rubber plant [5].

A linamarin is a cyanogenic glucoside [6]. The molar mass of linamarin is $247.21 \mathrm{~g} \mathrm{~mol}^{-1}$ and the density is $1.41 \mathrm{~g} \cdot \mathrm{cm}^{-3}$. The hydrolysis or cyanogensis of linamarin by endogenous enzyme, linamarase ( $\beta$-glucosidase), results in the formation of glucose and acetone cyanohydrin, which later decomposes into hydrogen cyanide $(\mathrm{HCN})$ and acetone $[7,8]$. The molecular formula of linamarin is $\left(\mathrm{C}_{10} \mathrm{H}_{17} \mathrm{NO}_{6}\right)$ shown in Figure 1.

The linamarin can be used as a substrate to detect the activity of enzyme linamarase it can also be used in the preparation of standard linamarin filter paper discs which are used to monitor the performance of picrate kits for determination of total cyanide, purified linamarin can also be used as an enzyme-prodrug system in cancer 


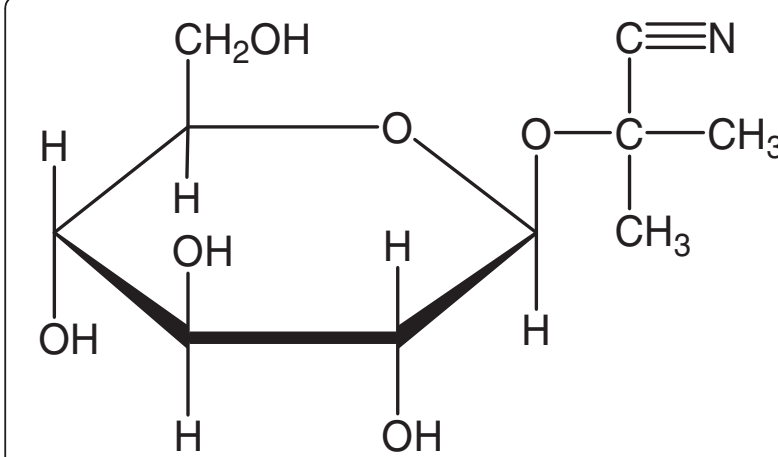

Figure 1 Molecular formula of linamarin.

gene therapy [8]. The linamarin has been demonstrated to protect the plant from herbivore insect feeders [9].

In this paper, analysis the toxin of linamarin in the RSO by using different solvents extraction, such as, hexane, chloroform + methanol and ethanol were carried out. The Fourier transforms infrared spectroscopy (FTIR) analysis, colorimetric method based on the könig reaction, rats toxicological test and shrimps toxicological test were also carried out. Analysis of linamarin is playing a vital role to determine the validity of the use of the RSO as a healthy type of diet to be consumed by animal. It has various beneficial advantages to human being as well. Hence, determination of the physicochemical characteristics and toxin compound (linamarin) in the RSO are dominantly important to be scientifically researched before the RSO can be used for both animal and human consumption.

\section{Results and discussions}

The physicochemical properties of RSO determined are given in (Table 1). The color of RSO present as pale yellow oil (33.98 \pm 0.08$)$, and darker (lower $L^{*}$ value) than commercial oils (66.8-68.1) such as corn oil, Soya bean oil and sunflower oil [10]. The present FFA $(7.55 \pm 0.02 \%$, as oleic

Table 1 The physicochemical properties of RSO

\begin{tabular}{ll}
\hline Analysis & RSO \\
\hline FFA\% (as oleic) & $7.55 \pm 0.02$ \\
Acid value (mg KOH/g) & $15.03 \pm 0.04$ \\
lodine value (wijs) & $135.79 \pm 0.33$ \\
Saponification value (mg/g) & $182.12 \pm 0.27$ \\
Unsaponifiable matter (\%) & $1.83 \pm 0.01$ \\
Color & \\
$a^{*}$ & $0.86 \pm 0.01$ \\
$b^{*}$ & $0.47 \pm 0.04$ \\
$L^{*}$ & $33.98 \pm 0.08$ \\
Average M.wt of TAG & $924.12 \pm 8.89$ \\
\hline
\end{tabular}

acid) and acid value $(15.03 \pm 0.04 \mathrm{mg} \mathrm{KOH} / \mathrm{g})$ for $\mathrm{RSO}$ show that the RSO has a high FFA\% due to the RSO was not neutralized. The RSO shows high iodine value $(135.79 \pm 0.33)$ comparing with iodine value of palm oil (52) [11] due to the high content of unsaturated fatty acids such as oleic acid (22.9\%) is shown in (Table 2).

The Saponification value of RSO $(182.12 \pm 0.27 \mathrm{mg} / \mathrm{g})$ similar to the other typical seed oil such as sunflower, and corn oil [12] and lower than the other vegetable oil such as, coconut, melon, groundnut, oil bean seed, and palm kernel seed, on the other hand its higher than castor [10], and perah oil [13], with average range saponification number of (175-250) [14]. The unsaponifiable matter is important to determine the quantity of substances present in the RSO and the quality of RSO. The value of unsaponifiable matter of RSO is $1.83 \pm 0.01 \%$ (Table 1 ). This value is in agreement with the value reported in by [2].

The fatty acid composition of the RSO is shown in (Table 2). The fatty acids of RSO consist from saturated FA $(19.12 \pm 0.28 \%)$ and unsaturated FA $(79.45 \pm 0.31 \%)$. The saturated FA are consisting mainly palmitic acid $(8.56 \pm 0.07 \%)$ and stearic acid $(10.56 \pm 0.02 \%)$, and unsaturated FA are consisting mainly oleic acid (22.95 $\pm 0.15 \%)$, linoleic acid (37.28 $\pm 0.10 \%)$, and linolenic acid (19.22 $\pm 0.21 \%)$. The fatty acid composition of RSO can be used as indicator of type of each fatty acid [15].

The toxicological compound such as linamarin in RSO extracted using hexane was also carried out. The main peaks and their assignment to functional groups are given in Table 3. FTIR spectrum analysis was carried out to determine the presence of such compounds. The carbonyl band occurs as a doublet. Probably FTIR spectrum showed characteristics absorption bands of RSO at wave number $\left(1744 \mathrm{~cm}^{-1}\right)$ for the ester carbonyl functional groups $(\mathrm{C}=\mathrm{O})$. Peaks at 3009, 2924, 2925 and $2854 \mathrm{~cm}^{-1}$ indicated the $\mathrm{CH}_{2}$ and $\mathrm{CH}_{3}$ scissoring of RSO. The FTIR

Table 2 Fatty acids composition of RSO

\begin{tabular}{ll}
\hline Fatty acids composition & RSO $\%$ \\
\hline Saturated & \\
Palmitic acid & $8.56 \pm 0.07$ \\
Stearic acid & $10.56 \pm 0.02$ \\
Total & $19.12 \pm 0.28$ \\
Unsaturated & \\
Oleic acid & $22.95 \pm 0.15$ \\
Linoleic acid & $37.28 \pm 0.10$ \\
Linolenic acid & $19.22 \pm 0.21$ \\
Total & $79.45 \pm 0.31$ \\
Others & $1.43 \pm 0.07$ \\
\hline
\end{tabular}


Table 3 The main peaks in the FTIR functional groups of RSO

\begin{tabular}{ll}
\hline Wavelength of RSO & Functional group \\
\hline 3009 & O-H stretching vibration (alcohol) \\
2921,2854 & C-H stretching vibration (aliphatic) \\
1744 & C=O stretching vibration (ester) \\
1711 & C=O stretching vibration (carboxylic acid) \\
1463,1413 & C=C bending vibration (aliphatic) \\
$1284,1244,1166$ & C-O-C stretching vibration (ester) \\
722 & C-H group vibration (aliphatic) \\
\hline
\end{tabular}

spectroscopy analysis of RSO indicated presence of sharp peaks at $1463-1413 \mathrm{~cm}^{-1}$ which belong to double bond $(\mathrm{C}=\mathrm{C})$ (Aliphatic). The peaks at $1284-1244 \mathrm{~cm}^{-1}$ of $\mathrm{RSO}$ referred to $(\mathrm{C}-\mathrm{O}-\mathrm{C})$ stretching. The peaks at $1711 \mathrm{~cm}^{-1}$ of RSO referred to the presence of $(-\mathrm{COOH})$ carboxylic acid. FTIR spectrum also showed absorption bands at $722 \mathrm{~cm}^{-1}$ for $(\mathrm{C}-\mathrm{H})$ group vibration. FTIR spectrum of RSO did not show any presence of cyanide peak. The result shows that no functional groups that associated with linamarin.

Two RSO were studied for cyanide determination. The RSO which was studied in this method was extracted using hexane as a solvent. The commercial cyanide was used as a standard and was compared with RSO which was extracted using hexane. The determination of cyanide demonstrated no response of the cyanide in RSO and did not show any colored comparing with commercial cyanide which observed blue color. The results of current method support the FTIR method that no cyanide observed in this measurement. The commercial cyanide showed high response at $630 \mathrm{~nm}$ which is reported at [16]. The colorimetric method based on könig reaction showed no response for the detection of cyanide in the RSO. The response of cyanide and RSO are shown in Figure 2.
Table 4 Rats toxicological test: six rats

\begin{tabular}{lllll}
\hline Activity & Blank/Control & $\mathbf{R S O}_{\mathbf{h}}$ & $\mathbf{R S O}_{\mathbf{c h}+\mathbf{m t h}}$ & $\mathbf{R S O}_{\text {eth }}$ \\
\hline Color & White & No changes & No changes & No changes \\
Behavior & Normal & No changes & No changes & No changes \\
Mortality & No & No & No & No \\
\hline
\end{tabular}

Note: $\mathrm{RSO}_{\mathrm{h}}$ : $\mathrm{RSO}$ was extracted using hexane as solvent, $\mathrm{RSO}_{\mathrm{ch}+\mathrm{mth}}$ : $\mathrm{RSO}$ was extracted using mixture of chloroform and methanol as solvent, $\mathrm{RSO}_{\text {eth }}$ : RSO was extracted using ethanol as solvent, Blank: rats food.

Toxicological evaluation of the RSO was carried out in white male rats by performing an acute toxicity limit test to assess its acute toxicity potential in 3 months feeding study. Three different types of RSO were extracted by using different solvents, such as, hexane $\left(\mathrm{RSO}_{\mathrm{h}}\right)$, chloroform + methanol $\left(\mathrm{RSO}_{\mathrm{ch}+\mathrm{mth}}\right)$ and ethanol $\left(\mathrm{RSO}_{\text {eth }}\right)$, in the same extracting condition. Table 4 shows the mortality, color and behavior of the male white rats.

The results of the current study were in agreement with the above FTIR analysis. No acute toxic potential was observed with RSO. The male white rats did not display any behavioral changes and there was no mortality in any of the groups during the 3 months feeding study. The color of the male white rats didn't show any change during this study period.

The $\mathrm{RSO}_{\mathrm{h}}, \mathrm{RSO}_{\mathrm{ch}+\mathrm{mth}}$ and $\mathrm{RSO}_{\text {eth }}$ had no adverse effect on the rats food consumption. A similar increase in the average daily gain of rats fed with $\mathrm{RSO}_{\mathrm{h}}, \mathrm{RSO}_{\mathrm{ch}+\mathrm{m} t \mathrm{~h}}$ and $\mathrm{RSO}_{\text {eth }}$ was also observed; however, the differences between the 3 white male rats were not statistically significant. The 3 male rats showed no significant difference in body weight gain, food efficiency, body waist measurement and body height measurement. The growth rate of 3 white male rats is shown in Table 5 and Figure 3. These results indicated that $\mathrm{RSO}_{\mathrm{h}}, \mathrm{RSO}_{\mathrm{ch}+\mathrm{m} t h}$ and $\mathrm{RSO}_{\text {eth }}$ had no toxic or antipalatability effects depending on the statistical analysis of p-value $(P<0.05)$ $[2,17]$.

Table 6 shows the relationship between the samples of the linamarin which was extracted from the RSO using
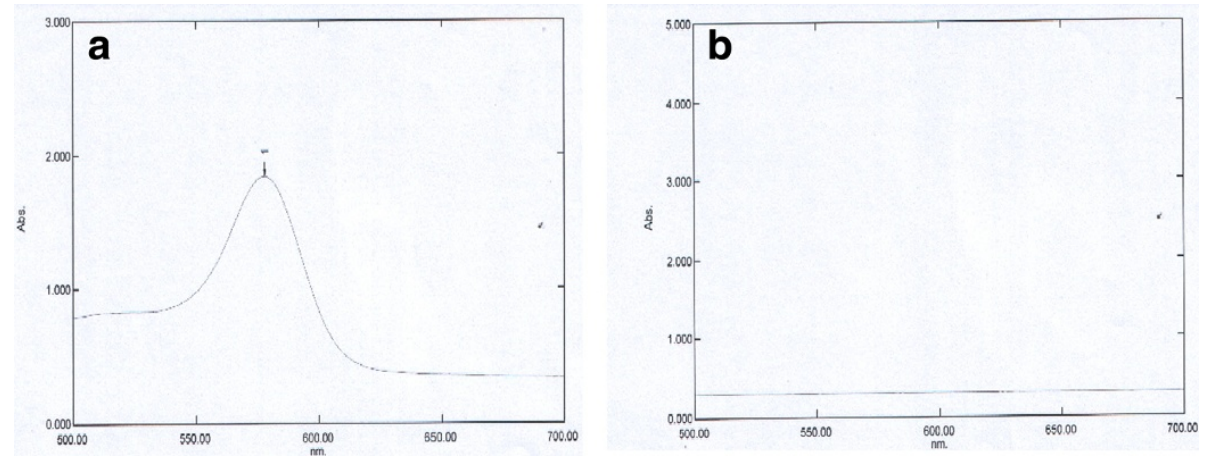

Figure 2 The response of cyanide (a) and RSO (b). 
Table 5 Effect of RSO intake: six rats

\begin{tabular}{|c|c|c|c|c|}
\hline Activity & Blank/Control & $\mathrm{RSO}_{\mathrm{h}}$ & $\mathrm{RSO}_{\mathrm{ch}+\mathrm{mth}}$ & $\mathrm{RSO}_{\text {eth }}$ \\
\hline Initial body weight (g) & $248.8 \pm 0.2$ & $248.2 \pm 0.6$ & $248.5 \pm 0.7$ & $248.1 \pm 0.2$ \\
\hline Final body weight $(\mathrm{g}$ ) & $480.1 \pm 0.7$ & $482.1 \pm 0.2$ & $480.8 \pm 0.5$ & $479.7 \pm 0.3$ \\
\hline Body weight gain (g) & $232.1 \pm 0.6$ & $234.4 \pm 0.6$ & $232.8 \pm 0.2$ & $231.5 \pm 0.2$ \\
\hline Food consumption (g) & $1789.8 \pm 1.7$ & $1800.2 \pm 0.7$ & $1792.6 \pm 1.2$ & $1783.9 \pm 1.8$ \\
\hline Food efficiency ratio (weight gain/ food intake) & $0.15 \pm 0.02$ & $0.13 \pm 0.07$ & $0.13 \pm 0.01$ & $0.12 \pm 0.03$ \\
\hline Initial body waist (cm) & $14.5 \pm 0.6$ & $14.5 \pm 0.2$ & $14.5 \pm 0.1$ & $14.5 \pm 0.7$ \\
\hline Final body waist $(\mathrm{cm})$ & $20.2 \pm 0.2$ & $20.5 \pm 0.7$ & $20.5 \pm 0.3$ & $20.3 \pm 0.2$ \\
\hline Body wasit gain $(\mathrm{cm})$ & $5.7 \pm 0.6$ & $6.0 \pm 0.7$ & $6.0 \pm 0.1$ & $5.8 \pm 0,5$ \\
\hline Initial body tall (cm) & $23.4 \pm 0.3$ & $23.1 \pm 0.5$ & $23.7 \pm 0.3$ & $23.5 \pm 0.7$ \\
\hline Final body tall (cm) & $24.3 \pm 0.9$ & $24.5 \pm 0.2$ & $24.2 \pm 0.7$ & $24.2 \pm 0.1$ \\
\hline Body tall gain $(\mathrm{cm})$ & $1.3 \pm 0.7$ & $1.5 \pm 0.7$ & $1.2 \pm 0.2$ & $1.2 \pm 0.3$ \\
\hline Condition* & Normal & Normal & Normal & Normal \\
\hline
\end{tabular}

Note: $\mathrm{RSO}_{\mathrm{h}}$ : RSO was extracted using hexane as solvent, $\mathrm{RSO}_{\mathrm{ch}+\mathrm{mth}}$ : RSO was extracted using mixture of chloroform and methanol as solvent, $\mathrm{RSO} \mathrm{eth}_{\mathrm{e}}$ RSO was extracted using ethanol as solvent, Blank: rats food, condition*: condition was assessed by visual appearance.

different solvents, such as $\mathrm{RSO}_{\mathrm{h}}, \mathrm{RSO}_{\mathrm{ch}+\mathrm{mth}}$ and $\mathrm{RSO}_{\text {eth }}$ in the same extracting condition, concentration and the mortality rate of the shrimps. Sodium cyanide was used as a blank control in the palm oil and rubber seed (RS) tests for purposes of comparing the RSO. The estimated LC50 values and their confidence limits that resulted from the samples' acute toxicity tests on freshwater shrimps using samples of the linamarin were extracted from the $\mathrm{RSO}_{\mathrm{h}}, \mathrm{RSO}_{\mathrm{ch}+\mathrm{m} \text { th }}, \mathrm{RSO}_{\text {eth }}, \mathrm{RS}$, palm oil and cyanide standard and are as listed in Table 7.

Based on Finneys Probit Analysis Method (using EPA software program), the mean LC50 value of samples of the linamarin extracted from the $\mathrm{RSO}_{\mathrm{h}}, \mathrm{RSO}_{\mathrm{ch}+\mathrm{mth}}$, $\mathrm{RSO}_{\text {eth }}$, RS, palm oil and cyanide standard using shrimps were found to be $211.70 \%, 139.40 \%, 117.41 \%, 40.59 \%$, $139.40 \%$ and $0.63 \%$ respectively.

Shrimp has, for the first time, been used as a test organism for acute toxicity of linamarin in RSO and RS. The results showed that samples of the linamarin extract

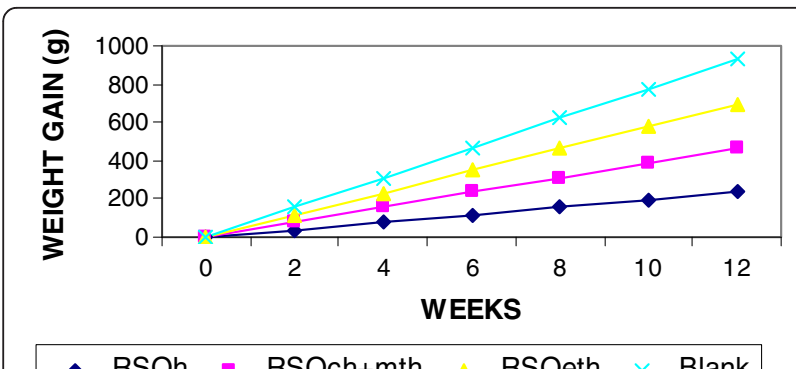

RSOh - RSOch+mth $\simeq$ RSOeth $x$ Blank

Figure 3 Body weight gain of rats feed RSO and blank control. Note: $\mathrm{RSO}_{\mathrm{h}}$ : RSO was extracted using hexane as solvent, $\mathrm{RSO}_{\mathrm{ch}+\mathrm{mth}}$ : RSO was extracted using mixture of chloroform and methanol as solvent, $\mathrm{RSO}_{\text {eth }}$ : RSO was extracted using ethanol as solvent, Blank: rats food. from the $\mathrm{RSO}_{\mathrm{h}}, \mathrm{RSO}_{\mathrm{ch}+\mathrm{mth}}$ and $\mathrm{RSO}_{\text {eth }}$ had no toxicity effect to shrimps (LC50 $211.70 \%, 139.40 \%$ and $117.41 \%)$, as this can be attributed to the absence of hazardous linamarin in RSO. The results of the samples which were extracted from the RS showed toxic effect in shrimps LC50 was found to be $40.59 \%$ as compared with samples which were extracted from RSO that may contain copper which produced the toxic effect [18]. The results of RSO and RS were compared with the palm oil and standard $\mathrm{NaCN}$. The palm oil did not show any toxic effect with LC50 (139.40\%). NaCN contained high toxicity to the shrimps with LC50 (0.63\%). These results would indicate that $\mathrm{RSO}_{h}, \mathrm{RSO}_{\mathrm{ch}+\mathrm{mth}}$ and $\mathrm{RSO}_{\text {eth }}$ had no acute toxicity in shrimp's organisms and supported the methods which used (FTIR, calorimetric method and rats toxicological test).

\section{Methods}

\section{Seed material and oil extraction}

Rubber seeds (RSs) were collected from (RRI) Sungai Buloh. The seeds were shelled and dried in the oven at $105{ }^{\circ} \mathrm{C}$ for $30 \mathrm{~min}$. The $\mathrm{RSs}$ were milled using the grinder. The seeds were kept in the refrigerator. RSO was extracted from the $500 \mathrm{~g}$ RSs by soxhlet extractor using hexane as solvent at $60{ }^{\circ} \mathrm{C}$ for 6 hours.

\section{Physicochemical characteristics}

The physicochemical properties of RSO such as color, FFA\%, acid value, saponification value, iodine value and unsaponifiable matter were determined according to [15].

\section{Gas chromatography (GC)}

The fatty acid composition of RSO was determined using its fatty acid methyl esters [19,20]. GC analysis was 
Table 6 Mortality percentage of shrimps at various concentrations of linamarin samples extracted from $\mathrm{RSO}_{\mathrm{h}}$, $\mathrm{RSO}_{\text {chl+mth}}, \mathrm{RSO}_{\text {eth }}, \mathrm{RS}$, palm oil and $\mathrm{NaCN}$

\begin{tabular}{|c|c|c|c|c|c|c|c|}
\hline Conc. (mL) & $\begin{array}{l}\text { Number } \\
\text { exposed }\end{array}$ & $\begin{array}{l}\text { Number response } \\
\text { of } \mathrm{RSO}_{\mathrm{h}}\end{array}$ & $\begin{array}{l}\text { Number response } \\
\text { of } \mathrm{RSO}_{\mathrm{chl}+\mathrm{mth}}\end{array}$ & $\begin{array}{l}\text { Number response } \\
\text { of } \mathrm{RSO}_{\text {eth }}\end{array}$ & $\begin{array}{l}\text { Number response } \\
\text { of RS }\end{array}$ & $\begin{array}{l}\text { Number response } \\
\text { of palm oil }\end{array}$ & $\begin{array}{l}\text { Number response } \\
\text { of cyanide }\end{array}$ \\
\hline 5 & 10 & 0 & 0 & 0 & 0 & 0 & 9 \\
\hline 10 & 10 & 0 & 0 & 0 & 2 & 0 & 9 \\
\hline 50 & 10 & 0 & 0 & 0 & 5 & 0 & 10 \\
\hline 75 & 10 & 1 & 1 & 1 & 7 & 1 & - \\
\hline 100 & 10 & 1 & 2 & 3 & 8 & 2 & - \\
\hline
\end{tabular}

Note: $\mathrm{RSO}_{\mathrm{h}}$ : RSO was extracted using hexane as solvent, $\mathrm{RSO}_{\mathrm{ch}+\mathrm{mth}}$ : RSO was extracted using mixture of chloroform and methanol as solvent, $\mathrm{RSO}$ eth: $\mathrm{RSO}_{\text {as }}$ extracted using ethanol as solvent, RS: RS extracted using water as solvent.

performed on shimadzu, GC equipped with flame ionization detectorand capillary column $(30 \mathrm{~m} \times 0.25 \mathrm{~mm} \times 0.25 \mu \mathrm{m}$ films). The detector temperature was programmed for $280^{\circ} \mathrm{C}$ with flow rate of $0.3 \mathrm{~mL} / \mathrm{min}$. The injector temperature was set at $250^{\circ} \mathrm{C}$. Nitrogen was used as the carrier gas at a flow rate of $20 \mathrm{~mL} / \mathrm{min}$.

\section{Fourier transforms infrared spectroscopy (FTIR)}

Fourier transforms infrared spectroscopy (FTIR) has been carried out according to [21]. FTIR of the products was recoded on a Prkin Elmer Spectrum GX spectrophotometer in the range $400-4000 \mathrm{~cm}-1$. FTIR was used to measure functional groups of RSO. A very thin film of $\mathrm{RSO}$ was covered on $\mathrm{NaCl}$ cells $(25 \mathrm{mmi} . \mathrm{d} \times 4 \mathrm{~mm}$ thickness) and was used for analysis.

\section{Colorimetric method Samples extraction}

The samples of linamarin extract were extracted from three different RSO (100 g) by using different solvents such as water $(20 \mathrm{~mL})$ and $0.25 \mathrm{M}$ chilled $\mathrm{H}_{2} \mathrm{SO}_{4}$ $(20 \mathrm{~mL})$ in separating funnel. After shaking the mixture gently, the mixture was left a few minutes to get two phases oil phase, and water phase or acidic phase. The oil phase was removed and the water phase or acidic phase was kept in the fridge [22,23].

\section{Hydrolysis of HCN in sample}

To conservation of cyanide, the samples were supplemented with $(4 \mathrm{~mL}) 10 \mathrm{M} \mathrm{NaOH}$. The sample was distilled without further pretreatment. $\mathrm{HCN}$ was recovered in the presence of $(10 \mathrm{~mL})$ zinc acetate buffer $\mathrm{pH} 4.5$. The remaining cyanide was subsequently recovered by distillation after addition $(5 \mathrm{~mL})$ of $\mathrm{MgCl}_{2}$ and $(5 \mathrm{~mL})$ sulfamic acid plus $(5 \mathrm{~mL}) 50 \% \mathrm{H}_{2} \mathrm{SO}_{4}$; the latter added to obtain $\mathrm{pH} 1-2$ for converting to $\mathrm{HCN}$ during distillation. After $3 \mathrm{~min}, 45 \mathrm{~mL} 50 \% \mathrm{H}_{2} \mathrm{SO}_{4}$ was added and the solution boiled under reflux for $90 \mathrm{~min}[22,23]$. The released $\mathrm{HCN}$ was determined using colorimetric method.

\section{Determination of $\mathrm{CN}$}

The detection of small amounts of cyanide, colorimetric method based on the könig reaction was proposed by [16]. This method involves the oxidation of cyanide to cyanogens chloride with chloramines T. Cyanogens chloride was then reacted with pyridine to form $\mathrm{N}$ cyanopyridinium chloride (könig reaction). The Ncyanopyridinium chloride was then reacted with barbituric acid to produce blue color was measured between 570-630 nm [16,24]. This method was preferable for cyanide at $3.8 \times 10-5 \mathrm{M}$. The reaction of the pyridinebarbituric acid method is shown in Figure 4. The same conditions were used to determine the $(C \equiv N)$ in sodium cyanide $(\mathrm{NaCN})$ which was used as a standard to compare it with $\mathrm{HCN}$ which was hydrolyzed from RS and RSO samples.

\section{Rats toxicological test}

Male white rats (Rumah Haiwan Laboratories) weighing between 284.1-284.8 grams were used and has been carried by [17]. The male white rats were individually housed

Table 7 The estimated LC values and confidence limits of toxicity on shrimps using the linamarin samples extracted from $\mathrm{RSO}_{\mathrm{h}}, \mathrm{RSO}_{\mathrm{chl}+\mathrm{mth}}, \mathrm{RSO}_{\mathrm{eth}}$, RS, palm oil and $\mathrm{NaCN}$

\begin{tabular}{lllllll}
\hline Point & $\begin{array}{l}\text { Exposure conc. } \\
\text { of } \mathbf{R S O}_{\mathbf{h}} \text { (mg/L) }\end{array}$ & $\begin{array}{l}\text { Exposure conc. of } \\
\mathbf{R S O}_{\text {chl+mth }} \text { (mg/L) }\end{array}$ & $\begin{array}{l}\text { Exposure conc. of } \\
\mathbf{R S O}_{\text {eth }}(\mathbf{m g} / \mathbf{L})\end{array}$ & $\begin{array}{l}\text { Exposure conc. } \\
\text { of RS (mg/L) }\end{array}$ & $\begin{array}{l}\text { Exposure conc. of } \\
\text { palm oil (mg/L) }\end{array}$ & $\begin{array}{l}\text { Exposure conc. of } \\
\text { cyanide (mg/L) }\end{array}$ \\
\hline LC 10.00 & 90.86 & 80.63 & 77.33 & 8.75 & 80.63 & 0.06 \\
LC 50.00 & 211.70 & 139.40 & 117.41 & 40.59 & 139.40 & 0.63 \\
LC 90.00 & 493.22 & 241.03 & 178.26 & 188.33 & 241.03 & 6.49 \\
\hline
\end{tabular}

Note: $\mathrm{RSO}_{\mathrm{h}}$ : RSO was extracted using hexane as solvent, $\mathrm{RSO}_{\mathrm{ch}+\mathrm{mth}}$ : $\mathrm{RSO}$ was extracted using mixture of chloroform and methanol as solvent, $\mathrm{RSO}$ eth: $\mathrm{RSO}_{\text {was }}$ extracted using ethanol as solvent, RS: RS extracted using water as solvent. 


$$
\mathrm{CN}^{-}+\text {Chloramine } \mathrm{T} \longrightarrow \begin{gathered}
\mathrm{ClCN} \\
\text { Cyanogen chloride }
\end{gathered}
$$

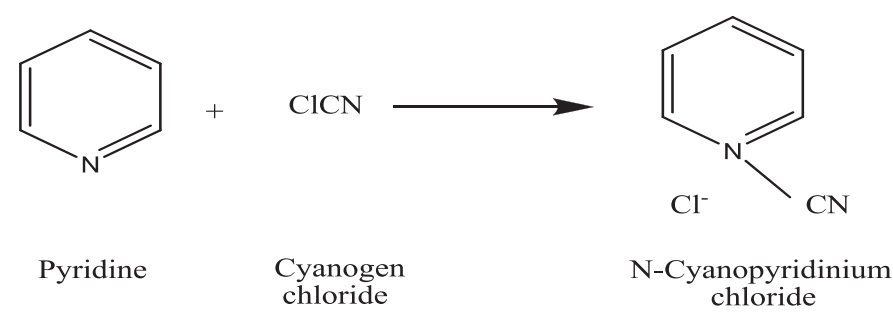

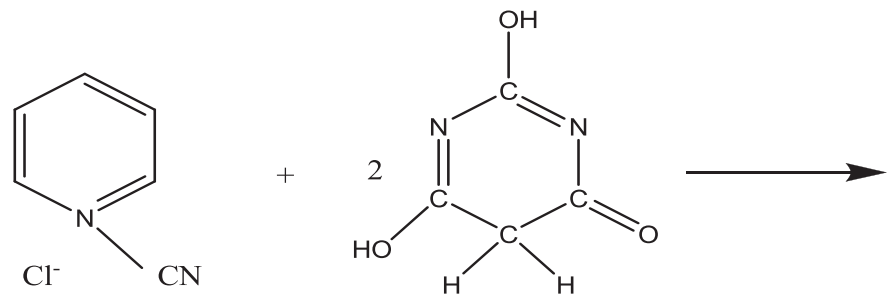

N-Cyanopyridinium

Barbituric acid<smiles>O=C1N=C(O)N=C(O)/C1=C\C=C\C=C\c1c(O)nc(O)nc1O</smiles>

Colored product

Figure 4 Colorimetric method reaction.

in stainless steel cages in a room with controlled temperature $\left(30-35^{\circ} \mathrm{C}\right.$ ) and lighting (alternative $12 \mathrm{~h}$ periods of light and darkness). The male white rats were fed a pelleted commercial laboratory for 3 months. The mortality, color, and the behavior of the male white rats were recoded daily but the food consumption was recorded every two weeks. The food consumption, food efficiency, body waist measurement and body tall measurement were also determined. Three experiments were conducted to determine the toxicological response of rats fed RSO. In experiment 1, rats were fed a RSO has been extracted by using hexane. In experiment 2, rats were fed a RSO has been extracted by using chloroform + methanol. In experiment 3, rats were fed a RSO has been extracted by using ethanol. The RSO was stored at $4{ }^{\circ} \mathrm{C}$ for feeding of rats. The toxicological evaluation of the RSO extracting by using three different solvents were carried out in male white rats by performing an acute oral toxicity limit test to assess its acute toxicity potential. The rats fed RSO were compared with rat fed normal food as blank.

\section{Shrimps toxicological test} Samples preparation

About $100 \mathrm{~g}$ of the RSs were homogenized with $160 \mathrm{~mL}$ of water. The homogenates were filtered through a filter cloth to remove insoluble materials. The homogenizer was rinsed with the water $(40 \mathrm{~mL})$ which was filtered in the same way. The filtrates were put it in the dried vacuum for 2 days. The precipitation was collected and stored in the fridge (a). RSO was extracted by using different solvents (hexane, chloroform + methanol and ethanol). The samples of linamarin were extracted from three different RSO (100 g) by using water as a solvent in separating funnel. After shaking the mixture gently, the mixture was left a few minutes to get two phases oil phase, and water phase. The oil phase was removed and the water phase was kept in the fridge (b).

\section{HCN hydrolysis}

To bind of cyanide, the samples were treated with $(4 \mathrm{ml})$ $10 \mathrm{M} \mathrm{NaOH}$. The sample was distilled without further 
pretreatment. $\mathrm{HCN}$ was recovered in the presence of $(10 \mathrm{~mL})$ zinc acetate buffer $\mathrm{pH} 4.5$. The remaining cyanide was subsequently recovered by distillation after addition ( $5 \mathrm{~mL}$ ) of $\mathrm{MgCl}_{2}$ and ( $5 \mathrm{~mL}$ ) sulfamic acid plus (5 mL) $50 \% \mathrm{H}_{2} \mathrm{SO}_{4}$; the latter added to obtain $\mathrm{pH} 1-2$ to release $\mathrm{HCN}$ during distillation. After $3 \mathrm{~min}, 45 \mathrm{~mL}$ $50 \% \mathrm{H}_{2} \mathrm{SO}_{4}$ was added and the solution boiled under reflux for $90 \mathrm{~min}[22,23]$. The samples after the distillation method were put it in a drying vacuum to evaporate the solvents. The released $\mathrm{HCN}$ was determined using acute toxicity method.

\section{Acute toxicity method}

Shrimps used in this study was obtained from a local breeder and transported immediately to the laboratory within $20 \mathrm{~min}$. In the laboratory, a total of 840 shrimps were kept in an 80-L glass aquarium containing filtered and dechlorinated tap water $(\mathrm{pH}$ 6.2-6.4, dissolved oxygen concentration 7.3-8.1 $\mathrm{mg} \mathrm{L}^{-1}$, conductivity 64-68 $\mu \mathrm{Scm}^{-1}$ and ammonia $\left.<0.5 \mathrm{mg} \mathrm{L}^{-1}\right)$. The shrimp was equipped with a water-cycling device by which the water was continuously aerated for one week to remove chlorine before the shrimp was introduced. Shrimps were acclimated for 14 days $\left(26-27{ }^{\circ} \mathrm{C}\right.$ with $12 \mathrm{~h}$ light: $12 \mathrm{~h}$ darkness) and fed daily. Care was taken in order to keep the mortality rate less than $5 \%$ for the whole acclimatization period. Acute toxicity test was performed according to the $[25,26]$ recommendations. Laboratory static tests were conducted to determine the median lethal concentrations (LC50).Ten shrimps of similar size were sampled and placed in the test chambers. Shrimps were exposed for 96 hours to different samples concentrations of 5, 10, 50, 75 and $100 \%$ of the samples which were extracted from RSO and RS. The test chambers were aerated throughout the test period. Physiochemical parameters of the water in the chambers such as $\mathrm{pH}$, conductivity, dissolved oxygen, and temperature were measured for each solution. The tests were repeated three times for both the control and each test solution. During the experiment, dead shrimps were removed and mortality of the shrimps exposed to various concentrations of samples was recorded after $6,12,18,24,48,72$, and 96 hours. LC50 was calculated based on Finneys Probit Analysis Method [27]. The same conditions were used to determine the $\mathrm{C} \equiv \mathrm{N}$ in sodium cyanide $(\mathrm{NaCN})$ which was used as a standard to compare it with $\mathrm{HCN}$, which was hydrolyzed from RS and RSO samples and was compared also with samples which were extracted from palm oil using water as solvent.

\section{Conclusions}

The results showed that no functional groups such as cyanide $(\mathrm{C} \equiv \mathrm{N})$ that associated with linamarin being obserbed. The current study has shown that RSO could be considered for edible use. These initial results indicate that the use of RSO as an edible oil will not be restricted by toxic factors.

\section{Competing interests}

The authors declare that they have no competing interests.

\section{Authors' contributions}

JS developed the concept, analyzed the data and drafted the manuscript. BMA performed the analysis of the toxin compound (linamarin) in the RSO by using different methods. NS advised on the methods of tests. All authors read and approved the final manuscript.

Acknowledgment

We thank UKM and the Ministry of Science and Technology for research grant UKM-GUP-NBT-08-27-113 and UKM-OUP-2012-139.

Received: 28 February 2012 Accepted: 15 May 2012

Published: 13 June 2012

\section{References}

1. Joseph R, Madhusoodhanan KN, Alex R, Varghese S, George KE, Kuriakose B: Studies on epoxidised rubber seed oil as secondary plasticizer/stabilizer for polyvinyl chloride. Plastics, Rubber and Composites 2004, 33:217-222.

2. Ghandhi VM, Cherian KM, Mulky MJ: Nutritional and toxicological evaluation of rubber seed oil. Journal of the American Oil Chemists' Society 1990, 67:883-886.

3. Salimon J, Abdullah BM: A study on the thermal properties and solid fat content of Malaysian rubber seed oil. The Malaysian Journal of Analytical Sciences 2009, 13:1-7.

4. Aigbodion Al, Menon ARR, Pillai CKS: Processability characteristics and physico-mechanical properties of Natural rubber modified with rubber seed oil and epoxidized rubber seed oil. J Appl Polym Sci 2000, 77:1413-1418.

5. Duke JA, Ducellier JL: CRC Hand book of alternative cash crops. United States of America: CRC press; 1993.

6. Abdullah BM, Salimon J: Toxicity study of Malaysian rubber (Hevea brasiliensis) seed oil. Asian Journal of Biochemistry 2010, 5:33-39.

7. Idibie CA, Davids H, lyuke SE: Cytotoxicity of purified cassava linamarin to a selected cancer cell lines. Bioprocess Biosystems Engineering 2007, 30:261-269.

8. Sornyotha S, Laykyu K, Laykyu K, Ratanakhanok chai K: Purification and detection of linamarin from cassava root cortex by high performance liquid chromatography. Food Chem 2007, 104:1750-1754.

9. Siritunga D, Sayre R: Engineering cyanogens synthesis and turnover in cassava (manihot esculenta). Plant Mol Biol 2004, 56:661-669.

10. Basbes S, Blecker C, Deroanne C, Drira NE, Hamadi A: Date seeds: chemical composition and characteristic profiles of the lipid fraction. Food Chem 2004, 84:577-584

11. Onyeike EN, Acheru GN: Chemical composition of selected Nigerian oil seeds and physicochemical properties of the oil extracts. Food Chem 2002, 77:431-437.

12. O'Brien RD: Formulating and processing for applications. seconded. Washington, DC: CRC press; 2004

13. Yong OY, Salimon J: Characteristics of Elateriospermum tapos seed oil as a new source of oilseed. Ind Crop Prod 2006, 24:146-151.

14. Gunstone FD, Harwood JL, Padley FB: The lipid hand book. second editionth edition.: Chapman \& Hall chemical Database; 1994.

15. Abdullah BM, Salimon J: Physicochemical characteristics of Malaysian rubber (Hevea brasiliensis) seed oil. Eur J Sci Res 2009, 31:437-445.

16. Mak KKW, Yanase H, Renneberg R: Cyanide fishing and cyanide detection in Coral reef fishing using chemical tests biosensors. Biosens Bioelectron 2005, 20:2581-2593.

17. Nwokolo E, Kitts DD, Kanhai J: Serum and liver lipids of rats fed rubber seed oil. Plant Foods for Human Nutrition 1988, 38:145-153.

18. Ukhun ME, Uwatse GM: Nutritional evaluation of selected Nigerian rubber seed products - a chemical approach. Plant Food for Human Nutrition 1988, 38:309-318

19. Salimon J, Abdullah BM, Salih N: Hydrolysis optimization and characterization study of preparing fatty acids from Jatropha curcas seed oil. Chemistry Central Journal 2011, 5:67. 
20. Salimon J, Abdullah BM, Salih N: Saponification of Jatropha curcas seed oil: optimization by D-optimal design. International Journal of Chemical Engineering 2012, 2012:574780.

21. Salimon J, Abdullah BM, Salih N: D-optimal design optimization of Jatropha curcas L. seed oil hydrolysis via alkali-catalyzed reactions. Sains Malaysiana 2012, 41:731-738.

22. Bjarnholt N, Laegdsmand M, Hansen HCB, Jacobsen OH, Mollar BL: Leaching of cyanogenic glycosides and cyanide from white clover green manure. Chemosphere 2008, 72:897-904.

23. Dzombak DA, Ghosh RS, Wong-chong GM: Cyanide in water and soil: Chemistry, Risk, and management. United States of America: CRC press; 2006.

24. Nambisan B, Sundaresan S: Spectrophotometric determination of cyanoglucosides in cassava. J Assoc Off Anal Chem 1984, 67:641-3.

25. Organization for Economic Co-operation and Development: OECD Guidelines for Testing of Chemicals. Paris: OECD; 1993.

26. APHA: Standard methods for the examination of water and wastewater. D.C: Washington; 1998

27. Center for Exposure Assessment Modeling (CEAM), US EPA: LC50 Software Program, Version 1.00. Washington, DC: CEAM Distribution Center; 1999.

doi:10.1186/1476-511X-11-74

Cite this article as: Salimon et al:: Rubber (Hevea brasiliensis) seed oil toxicity effect and Linamarin compound analysis. Lipids in Health and Disease 2012 11:74

\section{Submit your next manuscript to BioMed Central and take full advantage of:}

- Convenient online submission

- Thorough peer review

- No space constraints or color figure charges

- Immediate publication on acceptance

- Inclusion in PubMed, CAS, Scopus and Google Scholar

- Research which is freely available for redistribution 